\title{
Assessment of Gross Alpha and Beta Radioactivity in Some Vegetable Species of Komadugu Yobe Riverine Areas of Yobe State, Nigeria
}

\author{
${ }^{1,3}$ Isah N. F. ; ${ }^{2}$ Lawan M.A.; ${ }^{1,3}$ Ibrahim M.U and ${ }^{1,3}$ Ahmed F. \\ ${ }^{1}$ Department of Physics, \\ Faculty of Sciences, \\ Bayero University Kano \\ ${ }^{2}$ Department of Science Laboratory Technology, \\ School of Sciences, \\ Mai Idriss Alooma Polytechnic, \\ Geidam, Yobe State \\ ${ }^{3}$ Centre for Renewable Energy Research, \\ Bayero University Kano
}

Email: umibrahim.phy@buk.edu.ng

\begin{abstract}
Vegetables constitute an important part of human diet since they contain carbohydrates, proteins, vitamins and minerals. However, resulting from human and animal activities, it is usually contaminated with solid and human waste, effluents from chemical industries and radionuclides. This study investigated the gross alpha and beta activities (GABAs) in Vegetables of Komadugu-Yobe riverine areas of Yobe state, Nigeria. Vegetable (onion, pepper and tomato) samples were collected and analyzed using MPC-2000DP Low Background proportional counter. The GABA result indicated that all the alpha concentrations in all the three samples (onion,pepper and tomato) has alpha concentrations above the WHO benchmark except in location B (Azbak) for pepper sample which have value $0.09670 \pm 0.00260 \mathrm{~Bq} / \mathrm{kg}$. Beta activity concentrations in the samples analyzed across the study area were below the WHO $1.0 \mathrm{~Bq} / \mathrm{kg}$ benchmark. This is in agreement with previous study which revealed that beta concentrations of study area in river water samples along Komadugu-Yobe River were within the typical world average values. Based on the findings of the study, it can be concluded that all the vegetable samples analyzed have significant radiological health burden on the environment and the populace except locations B pepper. It is therefore recommended that efforts should be intensified to identify further sources of contaminations with a view to addressing the long standing renal and kidney failure experienced by people in the study area.
\end{abstract}

Keywords: gross alpha, gross Beta activity, Komadugu-Yobe River, radioactivity , proportional counter. 


\section{INTRODUCTION}

The need to quantify gross alpha and beta particles content of ingestible materials in human body is necessary as these particles have short ranges and could deposit a lot of energy within a tissue in which they are absorbed. They are inherently charged particles and are capable of causing greater damage due to gross ionization. Radionuclide which enter the human body via foodstuffs, reaches it through a complex mechanism or food chain (Amaral et al, 1998). The season of the year determines to a great extent the magnitude of contamination of different foods or environmental components (IAEA, 1989). Green leafy vegetables are prone to external contamination during their growing season, while root vegetables may also become contaminated (Badran et al, 2003). Vegetables may be subjected to direct and indirect contamination of Uranium series nuclides in vegetables. Naturally occurring Radionuclide (NORM) of Thorium and Uranium are significant contribution of ingestion dose and are present in the biotic systems of plants, animals, soil, water and air. Distribution of these radionuclides in different parts of the plants depends on the chemical characteristic and several parameters of the plant and soil (Shanthi et al, 2009 Adewumi et al 2016). Adewumi et al., measured the gross alpha and beta radioactivity in Vegetable and Fruit in Niger Delta region of Nigeria and obtained alpha activity in the study zones to be above WHO benchmark of $0.1 \mathrm{~Bq} / \mathrm{Kg}$ and beta activity were below benchmark of $1.0 \mathrm{~Bq} / \mathrm{kg}$ Oloma (1990). In a similar research it was found that, some food stuff in Nigeria contain radioactive materials as a results of application of fertilizer, nature of the soil and irrigation pattern during cultivation. Arogunjo lead his team in 2004 studied the level of natural radionuclide in some Nigerian cereals and tubers using HPGe detector and reported average concentration of ${ }^{40} \mathrm{~K}, 238 \mathrm{U}$ and $232 \mathrm{Th}$ as $130 \pm 8.12 \mathrm{~B}^{\mathrm{q}} \mathrm{kg}^{-1}, 11.5 \pm 3.86 \mathrm{~Bq} / \mathrm{kg}^{-1}$, and $6.78 \pm 2.1 \mathrm{~Bq} /$ $\mathrm{Kg}^{-1}$ respectively, while ${ }^{137} \mathrm{Cs}$ was not detected in any of food stuffs analyzed. Radionuclides have always been present in food at various levels depending on factors such as radioactivity contents in soil and the transfer characteristics from the environmental medium to foodstuff, and hence to man (Amaral et al,1998, IAEA,1989 and Thiry et al,2002).

Yobe state is a riverine area in which one of the major sources of revenue is agriculture and mining. Due to this activities report in hospital within the state has reported many cases of health challenges ranging from Cancer, Kidney disease and other renal failure. Base on this fact this research intend to investigate Gross alpha and beta radioactivity in some vegetables species of Komadugu - Yobe Rerine areas of Yobe State using proportional counter and compared the result with the WHO benchmark. This health challenges need to be properly investigated and possible reasons for this problems need to be identified. This research try to give a background and updated the data base Gross Alpha and Beta Activities in some selected vegetables.

\section{MATERIALS AND METHODS}

Study area: The Komadugu-Yobe River (KYR) is situated in the Sahel region in Africa, just south of the Sahara desert. It is located between latitude 10000 " $\mathrm{N}$ and 13000 " $\mathrm{N}$ and Longitude $9045^{\prime \prime} \mathrm{E}$ and $12^{\circ} 30$ " of the prime meridian. The area of study is Nguru-Gashua axis of the river which covers a distance of about $65 \mathrm{~km}$ along the river coast. It is the principal river in the state from which Yobe state derived its name. It has a few tributaries, which include river Hadeja, Jama're and river Alkalam. The farmers who live in this area generally rear animals, raise crops and some vegetables (YSPS, 2010).Agrochemicals such as fertilizers, pesticides, herbicides and refuse dump by the riverside are the main sources of contaminant of the vegetables since there are no large cities, no-nuclear enterprises such as radiochemical and phosphate industries and coal-fired power plants situated around the river coast. 


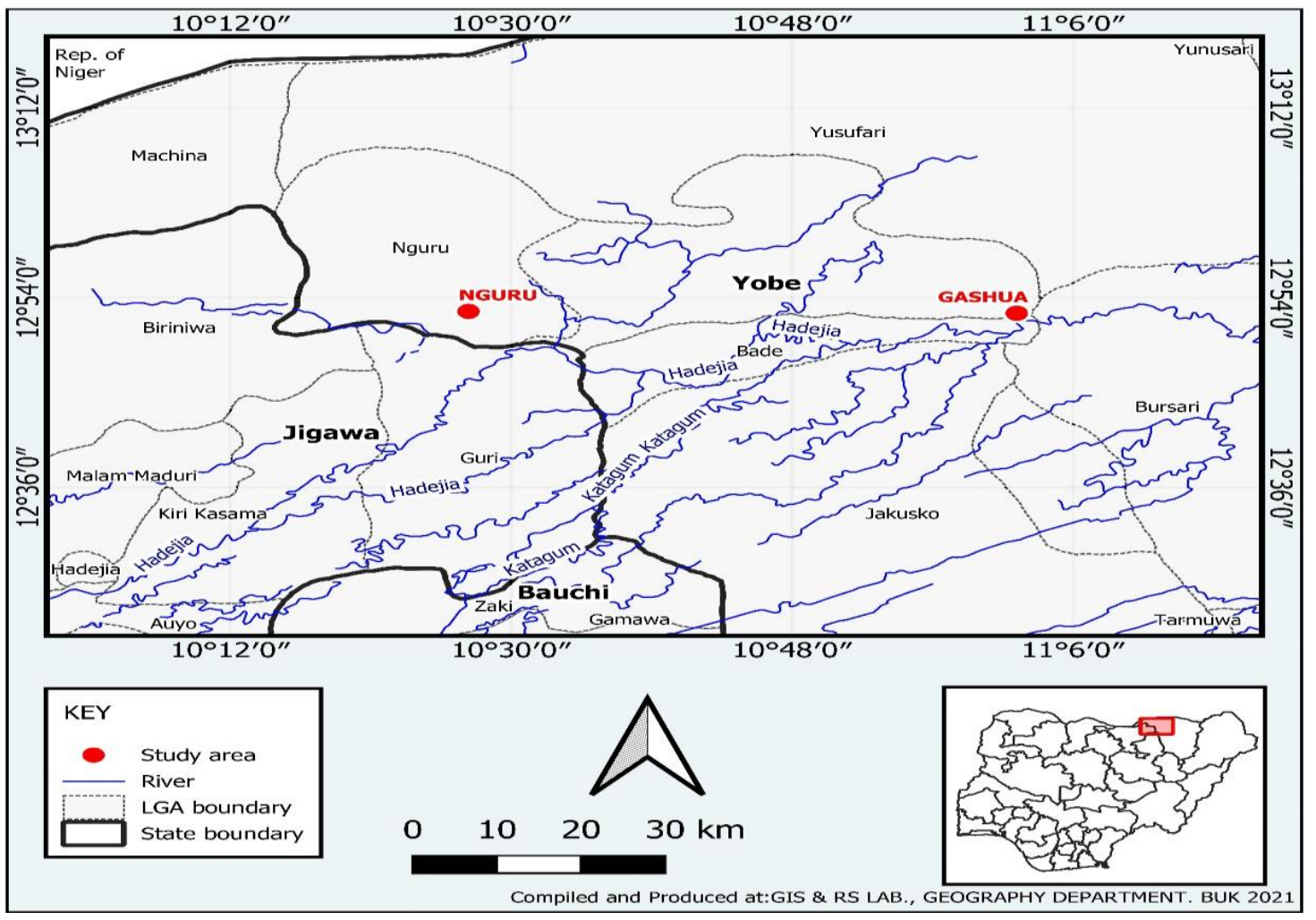

Figure 1: Map showing the Study Area

The rainfall in the study area is highly irregular which makes farming difficult since small differences in the amount and timing of rain received at a site may determine the success or failure of critical stages in vegetation development and crop production (YSPS, 2010). Therefore, the developments of agricultural activities heavily depend on irrigation farming. The mean annual temperature of the study area is $37^{\circ} \mathrm{C}$ with the highest temperature (about $42^{\circ} \mathrm{C}$ ) which is normally experienced in April, while minimum temperatures (about $30^{\circ} \mathrm{C}$ ) are usually recorded in December (Abba, 2013). The rainy season usually starts from June until September and the dry season is from October until May (Martinsson, 2010).This means that rainfall lasts for about 120 days with a marked dry season of eight to nine months and a wet season of only three to four months.

The vegetation of the study area is Sahel (desert) savannah. It is desert vegetation that is characterized by very short grasses and tussock of not more than one meter $(0.5 \mathrm{~m}$ to $1.0 \mathrm{~m})$ high interspersed and located in-between sand dunes. The area is dominated by several varieties of the acacia and date - palms (YSPS, 2010).

Materials: This research employ the following materials and equipment for GABA analysis

i Beaker $(500 \mathrm{ml})$

ii MPC 2000DP Low background

Proportional Counter

iii. Petri dish

iv. Police rubber

v. Weighing balance (Mettler AE240)

vi. Hand glove xii. GPS device. vii. Plastic container (2 litres)

viii. Desiccator

ix. Planchettes

$x$. Reagents (acetone and ethanol)

xi. Hot plate (adjustable)

xii Marker and masking tape 
Sample locations: Five (5) sample locations were cited along the Nguru-Gashua axis of the river Komadugu-Yobe with the aid of the Global Positioning System (GPS) device and coded as shown in Table 1.

Table 1: Sample locations, Names and codes of the Study Area

The study area was carefully selected base on the activities and sources of food, animals, raised crops and some vegetables. Other environmental activities that contribute to environment pollution was also considered. These locations were tabulated in table 1.

\begin{tabular}{|c|c|c|c|}
\hline $\mathrm{S} / \mathrm{N}$ & $\begin{array}{l}\text { Locations } \\
\text { codes names }\end{array}$ & $\begin{array}{c}\text { Latitude } \\
\text { coordinates }\end{array}$ & $\begin{array}{l}\text { Longitude } \\
\text { coordinates }\end{array}$ \\
\hline 1 & A Gashua & $12^{0} 53^{\prime} 00^{\prime \prime} \mathrm{N}$ & 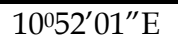 \\
\hline 2 & Azbak & $12^{051^{\prime} 00^{\prime \prime} \mathrm{N}}$ & $10^{0} 45^{\prime} 26^{\prime \prime} \mathrm{E}$ \\
\hline 3 & Karage & $12^{04} 5^{\prime} 00^{\prime \prime} \mathrm{N}$ & $10^{0} 42^{\prime} 00^{\prime \prime} \mathrm{E}$ \\
\hline 4 & Murza & $12^{0} 42^{\prime} 00^{\prime \prime} \mathrm{N}$ & $10^{0} 40^{\prime} 10^{\prime \prime} \mathrm{E}$ \\
\hline 5 & Wachakal & $12^{039^{\prime} 00^{\prime \prime} \mathrm{N}}$ & $10^{0} 34^{\prime} 00^{\prime \prime} \mathrm{E}$ \\
\hline
\end{tabular}

\section{Sample Collections}

A total of fifteen (15) samples were collected using standard method as reported by Isa et al. (2017). The vegetable samples collected were washed in order to remove and eliminate dust, dirt, possible parasite or their eggs. The vegetable fruit were separated and shed dried (i.e. air dried under shade). The dried samples crushed using ceramic coated grinder and subsequently the crushed samples were homogenized using sever. The homogenized samples were finally transferred into well labeled polythene bags at ambient temperature. These samples were then coded as A B C and D; Tomatoes (Lycoeriscum esculantus), Pepper (Capsicum spp) and Onion (Allium Cepa) respectively, similar to work by Isa et al (2018).

\section{Samples Preparation}

The samples were transferred to X-RD laboratory under Material Science and Development Section (MSDS), CERT, ABU Zaria, for pelletization process. Each sample was ground into a fine particles using electric grinding machine. Small portion of the samples was later transferred into the agate mortar and grounded further manually to a grain size of about $125 \mu \mathrm{m}$. Samples were weighed using analytical weighing balance. The appropriate/required weight of the sample for analysis was $0.5 \mathrm{~g}$ and three drops of organic liquid binder (made up of Toluene and Polyvinylchloride) was added. The sample with the liquid binder was ground until it is well mixed (homogenous). A pellet was circular disc of about $19 \mathrm{~mm}$ in diameter. The weight of the pellet was taken which should not be less than $0.4 \mathrm{~g}$ and finally the pellet was taken for alpha and beta radioactivity count using the gas-filled proportional counter. The activity count is an average value obtained at the end of three cycles of running the detector with pre-set time of 45 minutes each. MPC-2000DP Proportional Counter was used for the GABA count in the Alpha and Beta Counting Laboratory of Centre for Energy Research and Training (CERT), Ahmadu Bello University Zaria.Sr-90 (beta source) and Pu239 (alpha source) were used as calibration sources for MPC2000DP. Modified procedure of Isa et al., 2021.

\section{RESULTS}

The results for Alpha and Beta activities concentrations for Onion (A, B, C, D, E),Pepper $(\mathrm{A}, \mathrm{B}, \mathrm{C}, \mathrm{D}, \& \mathrm{E})$, and Tomato $(\mathrm{A}, \mathrm{B}, \mathrm{C}, \mathrm{D}, \& \mathrm{E})$ in the study areas as define in table 1 , were tabulated alongside their errors \pm in table 2 . These results were obtained using MPC-2000DP Low Background proportional counter. 
Table 2 : The results for Gross Alpha and Beta activity Concentrations (GABA) for these samples

\begin{tabular}{|c|c|c|c|c|c|}
\hline Sample ID & $\begin{array}{l}\text { Location code } \\
\text { Longitude } \\
\text { Latitude }\end{array}$ & $\begin{array}{ll}\text { Alpha } & \text { concentration } \\
(\mathrm{Bq} / \mathrm{kg}) & \end{array}$ & Error \pm & $\begin{array}{l}\text { Beta concentration } \\
(\mathrm{Bq} / \mathrm{kg})\end{array}$ & Error \pm \\
\hline G/ONION A & 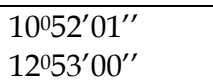 & 0.11251 & 0.00268 & 0.39037 & 0.00712 \\
\hline A/ONION B & 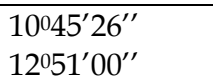 & 0.12461 & 0.00279 & 0.26575 & 0.00601 \\
\hline K/ONION C & 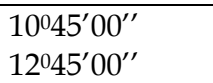 & 0.12907 & 0.00278 & 0.37525 & 0.00685 \\
\hline M/ONION D & $\begin{array}{l}10^{0} 40^{\prime} 10^{\prime \prime} \\
12^{0} 42^{\prime} 00^{\prime \prime}\end{array}$ & 0.11659 & 0.00244 & 0.20002 & 0.00478 \\
\hline W/ONION E & 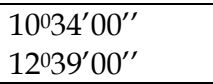 & 0.13603 & 0.00301 & 0.30658 & 0.00663 \\
\hline G/PEPPER A & 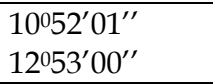 & 0.13603 & 0.00301 & 0.30658 & 0.00663 \\
\hline A/PEPPER B & 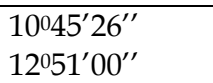 & 0.09670 & 0.00260 & 0.25664 & 0.00616 \\
\hline K/PEPPER C & $\begin{array}{l}10^{0} 45^{\prime} 00^{\prime \prime} \\
12^{0} 45^{\prime} 00^{\prime \prime}\end{array}$ & 0.12312 & 0.00262 & 0.24626 & 0.00547 \\
\hline M/PEPPER D & $\begin{array}{l}10^{0} 40^{\prime} 10^{\prime \prime} \\
12^{0} 42^{\prime} 00^{\prime \prime}\end{array}$ & 0.17058 & 0.00350 & 0.38580 & 0.00772 \\
\hline W/PEPPER E & 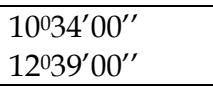 & 0.10945 & 0.00282 & 0.36133 & 0.00655 \\
\hline G/TOMATO A & 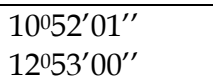 & 0.12356 & 0.00265 & 0.38580 & 0.00772 \\
\hline А/ТОМАТО В & $\begin{array}{l}10^{0} 45^{\prime} 26^{\prime \prime} \\
12^{0} 51^{\prime} 00^{\prime \prime}\end{array}$ & 0.10492 & 0.00255 & 0.29523 & 0.00620 \\
\hline К/ТОМАТО C & $\begin{array}{l}10^{0} 45^{\prime} 00^{\prime \prime} \\
12^{0} 45^{\prime} 00^{\prime \prime}\end{array}$ & 0.11924 & 0.00252 & 0.17008 & 0.00457 \\
\hline M/TOMATO D & $\begin{array}{l}10^{0} 40^{\prime} 10^{\prime \prime} \\
12^{0} 42^{\prime} 00^{\prime \prime}\end{array}$ & 0.10604 & 0.00246 & 0.29096 & 0.00589 \\
\hline W/TOMATO E & 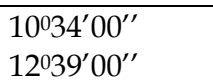 & 0.15354 & 0.00333 & 0.20520 & 0.00591 \\
\hline
\end{tabular}

\section{DISCUSSION}

From Table 2 the average alpha activity concentration in onion samples across the study area ranged from $0.11251 \pm 0.00268 \mathrm{~Bq} / \mathrm{kg}$ to $0.13603 \pm 0.00301 \mathrm{~Bq} / \mathrm{kg}$ and was of the order of $\mathrm{E}>\mathrm{C}>\mathrm{B}>\mathrm{D}>\mathrm{A}$ respectively. This work finding in terms of NORMs is in agreement with Mustapha (2019) and Adewumi (2016). In contrast, the average beta activity concentrations in onion samples in the study area was of the order of $A>C>E>B>D$, with a minimum beta concentration of $0.20002 \pm 0.00478 \mathrm{~Bq} / \mathrm{kg}$ and a maximum beta concentration of $0.39037 \pm 0.00712 \mathrm{~Bq} / \mathrm{kg}$ respectively. Similarly, the mean alpha activity concentrations in pepper samples in the study area was of the order of $D>A>C>E>B$, with a lowest alpha concentration value of $0.09670 \pm 0.00260 \mathrm{~Bq} / \mathrm{kg}$ and a highest alpha concentration value of $0.17058 \pm 0.00350 \mathrm{~Bq} / \mathrm{kg}$ respectively. While on the other hand, the average beta activity concentration in pepper samples across the study area ranged from $0.21485 \pm 0.00590 \mathrm{~Bq} / \mathrm{kg}$ to $0.38580 \pm 0.00772 \mathrm{~Bq} / \mathrm{kg}$ and was of the order of $\mathrm{D}>\mathrm{A}>\mathrm{B}>\mathrm{C}>\mathrm{E}$ respectively. However, the average alpha activity concentration in tomatoes `samples across the study area ranged from $0.10492 \pm 0.00255 \mathrm{~Bq} / \mathrm{kg}$ to $0.15354 \pm 0.00333$ and was of the order of $\mathrm{E}>\mathrm{A}>\mathrm{C}>\mathrm{D}>\mathrm{B}$ respectively. On the other hand, the average beta activity concentrations in tomatoes sample in the study area was of the order of $\mathrm{A}>\mathrm{B}>\mathrm{D}>\mathrm{E}>$, with a minimum beta concentration of $0.17008 \pm 0.00457 \mathrm{~Bq} / \mathrm{kg}$ and a maximum beta concentration of $0.36133 \pm 0.00655 \mathrm{~Bq} / \mathrm{kg}$ respectively, just like in the work of Isa et al. (2017) and Shanthi et al. (2009). 
The results in Table 2 is further discussed in bar charts as presented in figures $2-7$. These bar chart reveal the comparison of alpha and beta concentration against WHO, .2008 bench mark of $0.1 \mathrm{~Bq} / \mathrm{l}$ and $1.0 \mathrm{~Bq} / 1$.

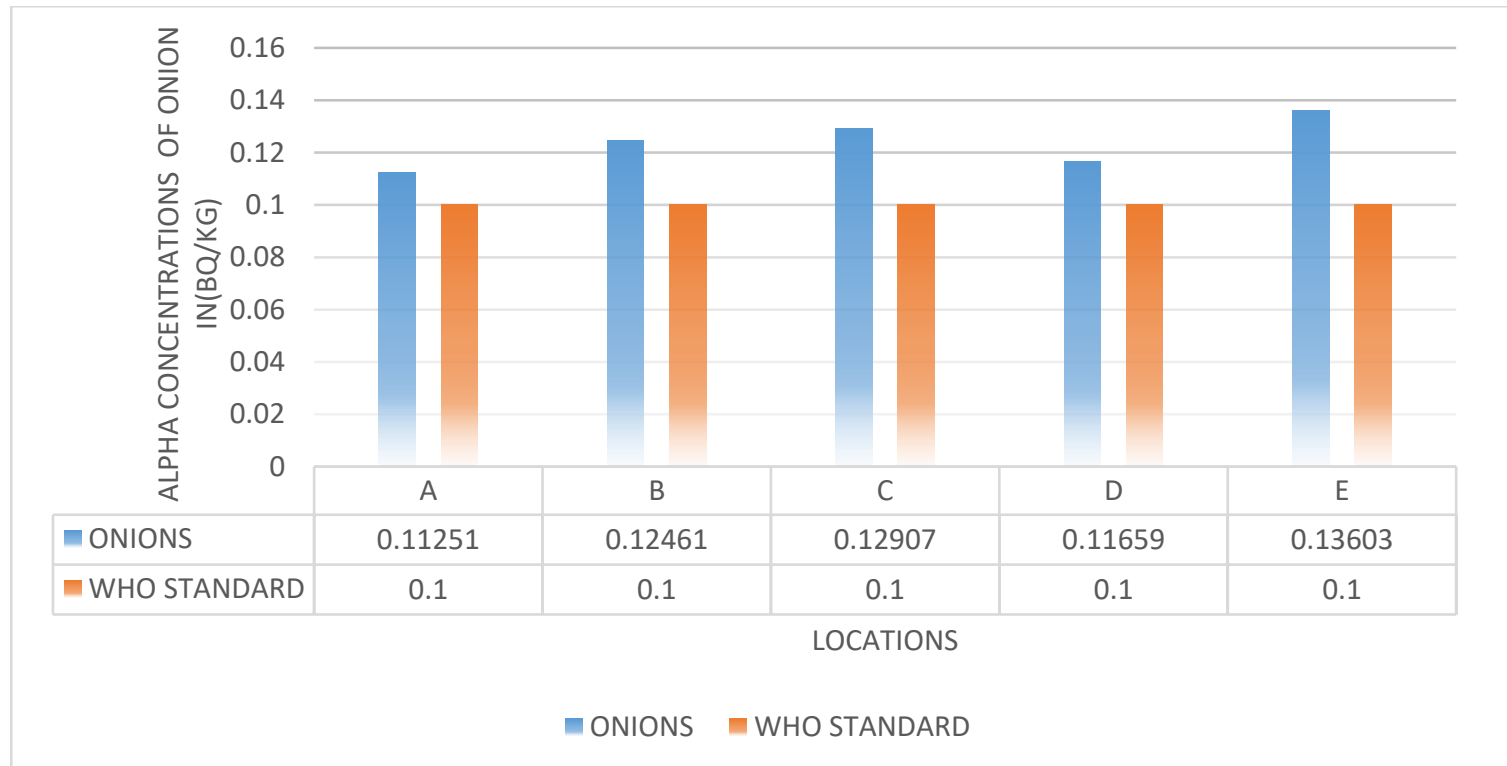

Figure 2: Comparison between mean alpha activity concentrations in onion samples of the study area and WHO bench mark.

Figure: 2. shows the bar chart comparison of mean alpha activity concentrations in onion samples of the study area and WHO (2008) vegetables standard. The result indicates that all the alpha activity concentrations in the onion samples across the study area were above the WHO bench mark. This finding is in agreement with the findings of Mustapha (2019) and Adewumi (2016).

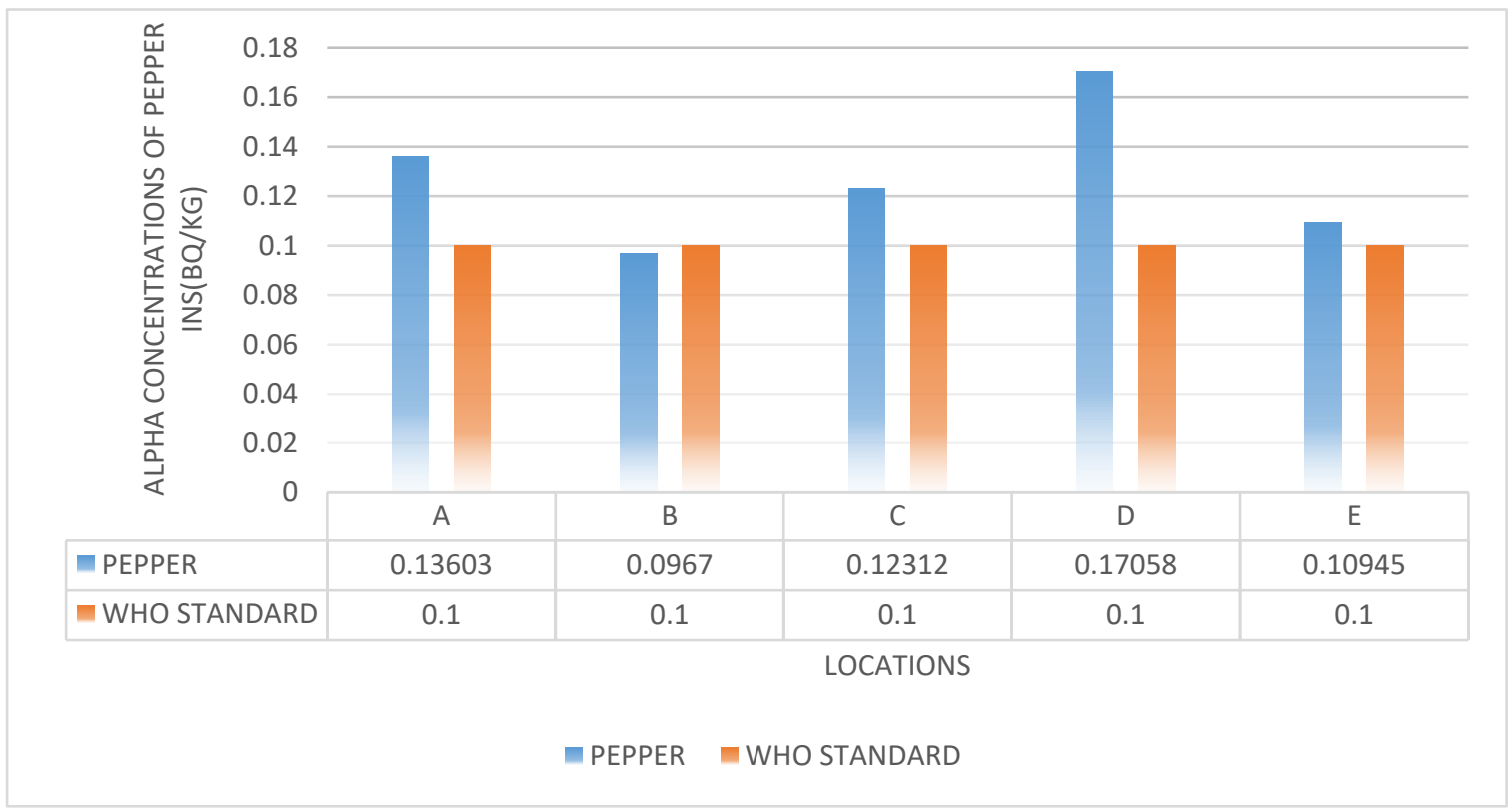

Figure 3: Comparison between mean alpha activity concentrations in pepper samples of the study area and WHO bench mark. 
The bar chart comparison of average alpha activity concentrations in pepper samples of the study area and WHO (2008) guidelines for vegetables bench mark shown in Figure 3: indicates that all the alpha activity concentrations in pepper samples across the study area were above the WHO bench mark except in location B where value of $0.09670 \pm 0.00260 \mathrm{~Bq} / \mathrm{L}$ alpha activity was found which is below WHO guideline for vegetable. This findings has shown agreement with guidline reported by IAEA (1989).

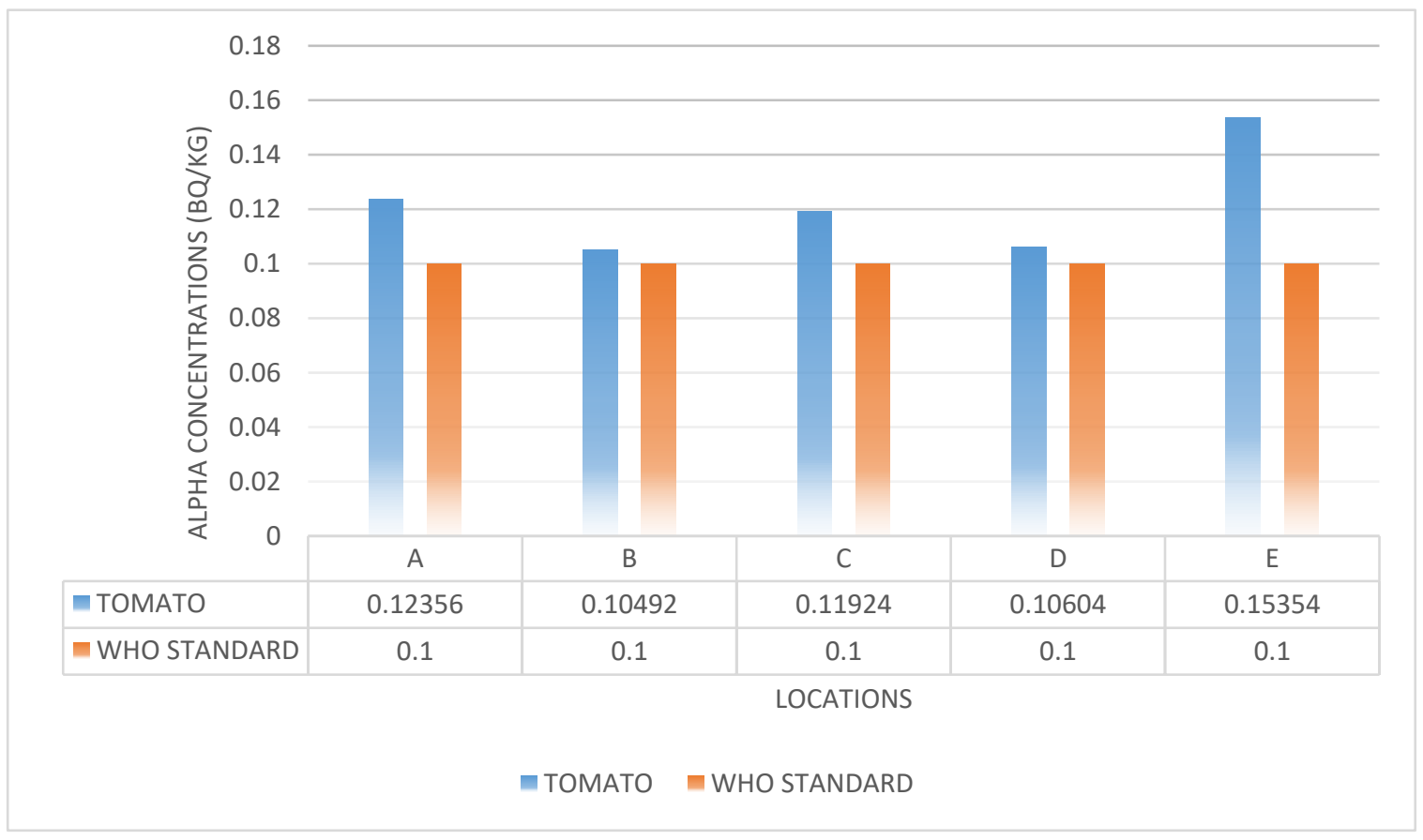

Figure 4: Comparison between mean alpha activity concentrations in tomato samples of the study area and WHO bench mark.

Figure .4: shows the bar chart comparison of mean alpha activity concentrations in tomato samples of the study area and WHO (2008) guidelines for vegetables bench mark. The result indicates that all the alpha activity concentrations in tomato samples across the study area were within the range of $0.10492 \pm 0.00255 \mathrm{~Bq} / \mathrm{L}$ to $0.15354 \pm 0.00333 \mathrm{~Bq} / \mathrm{L}$ which are above the WHO bench mark. This finding is alarming and very wide difference just like a similar work by Amara et al. (2013) and Olomo (1990) 


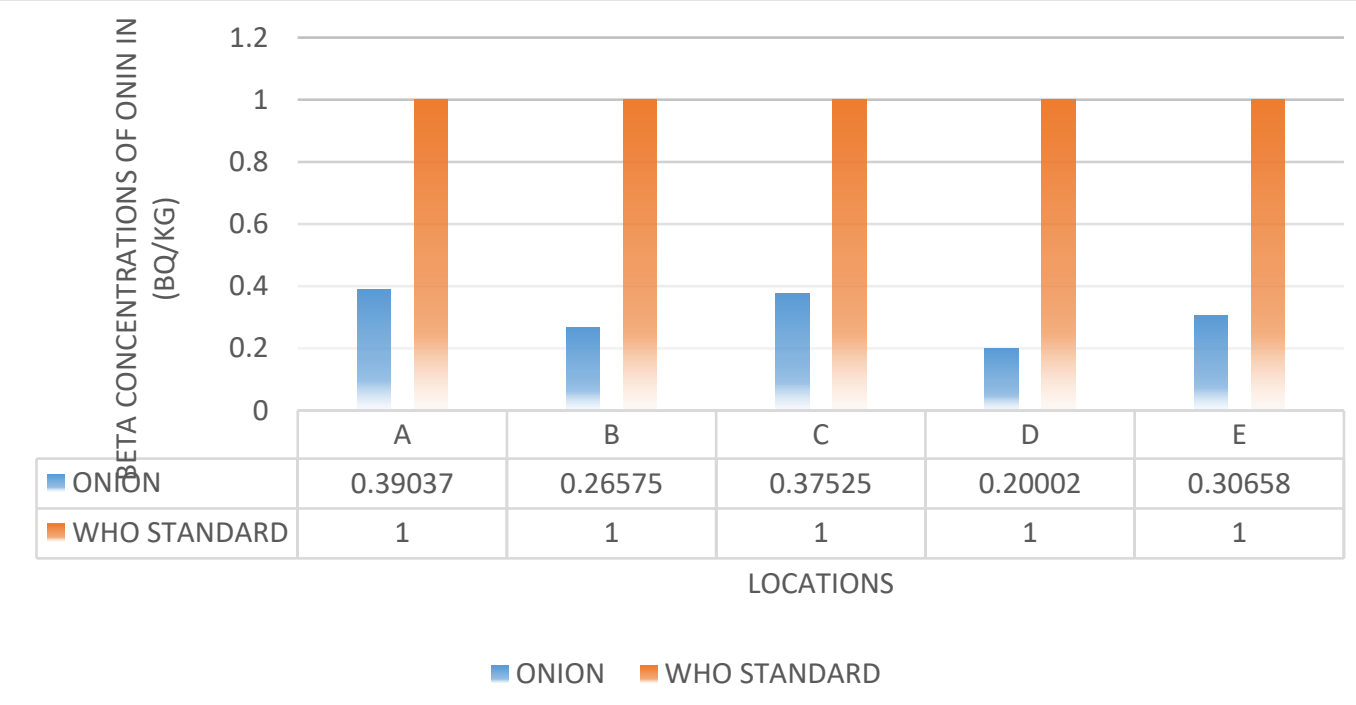

Figure 5: Comparison between mean beta activity concentrations in onion samples of the study area and WHO bench mark.

Figure 5: Shows the bar chart comparison of mean beta activity concentrations in onion samples of the study area and WHO (2008) guidelines for vegetable bench mark. The result indicates that all the beta activity concentrations in onion samples across the study area were below the WHO bench mark.

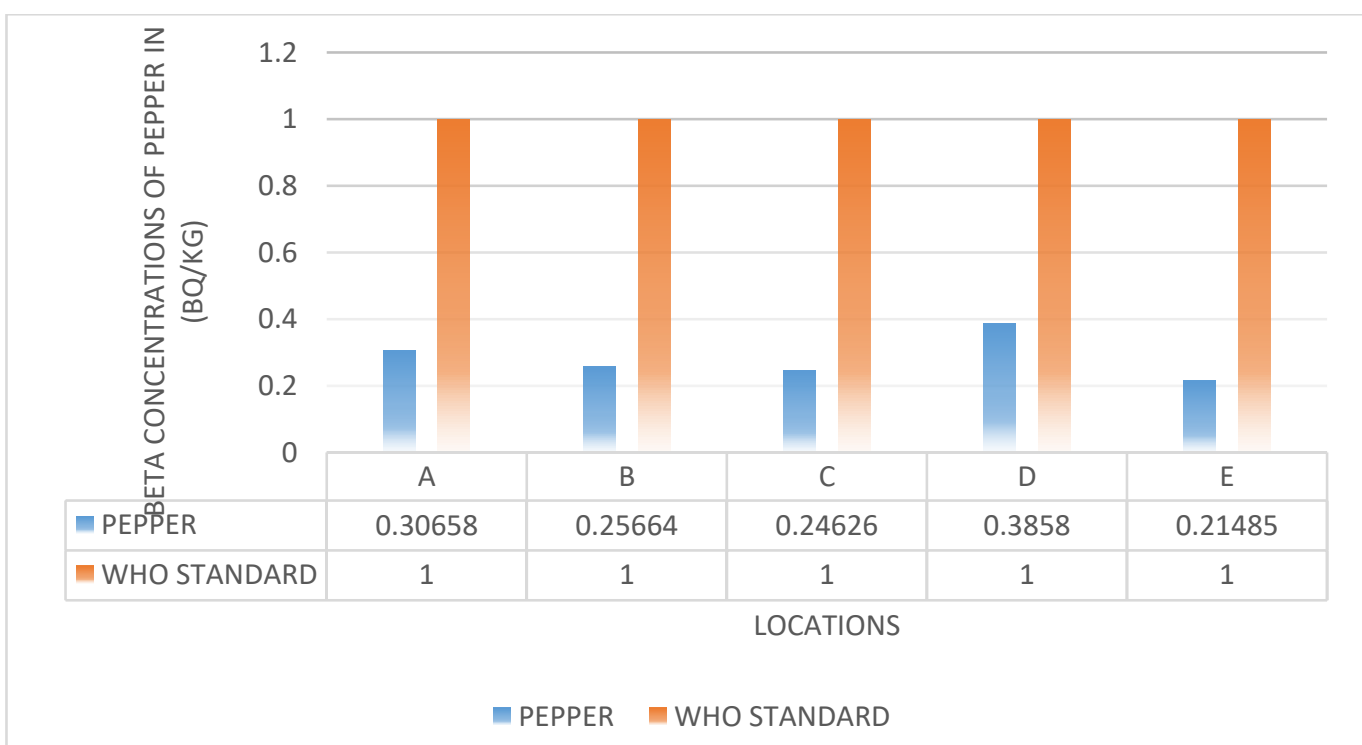

Figure 6: Comparison between mean beta activity concentrations in pepper samples of the study area and WHO bench mark.

Similarly, the bar chart comparison of average beta activity concentrations in pepper samples of the study area and WHO (2008) guidelines for vegetables bench mark shown in Figure 6: indicates that all the beta activity concentrations in pepper samples across the study area were below the WHO bench mark. 


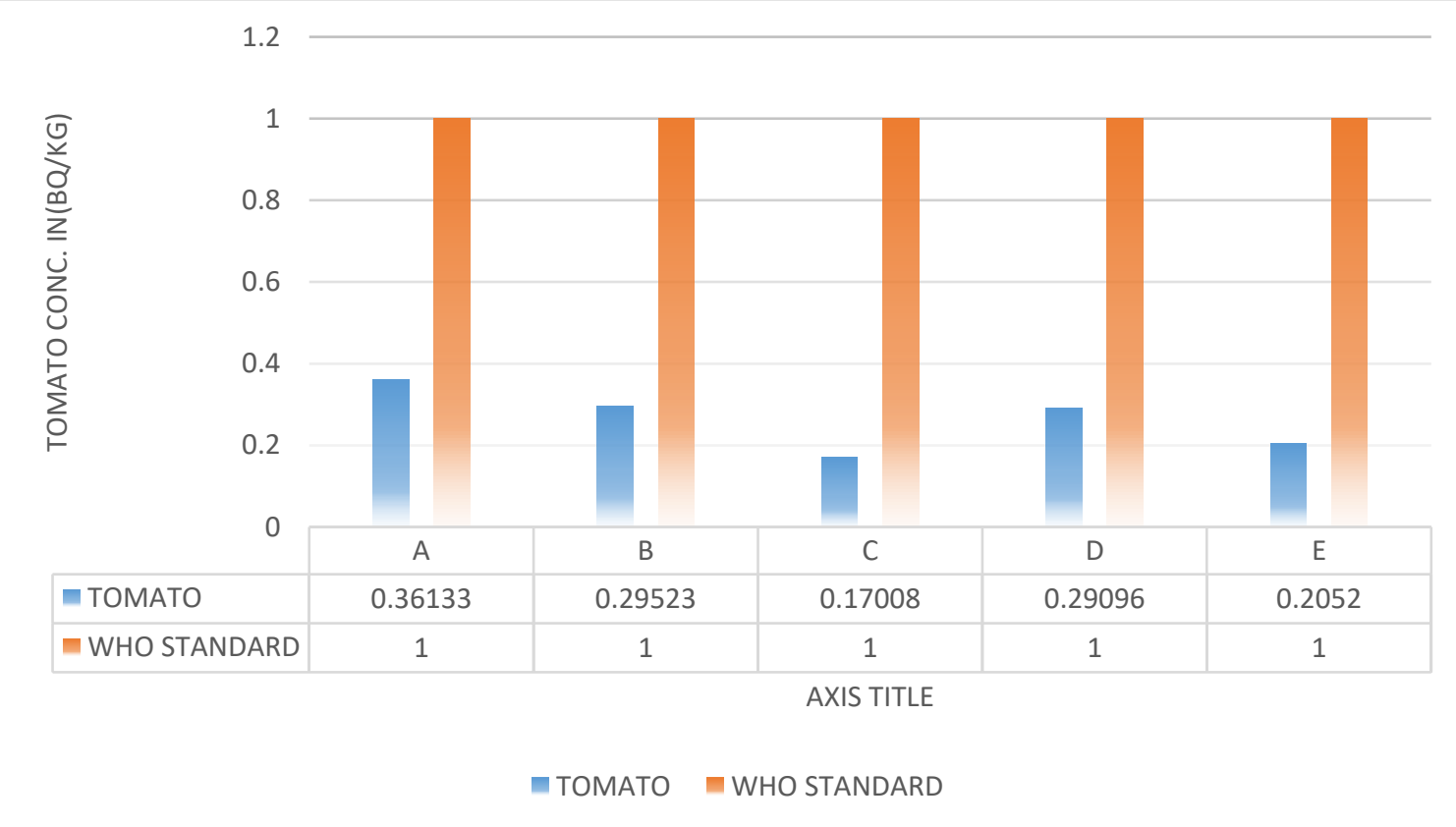

Figure 7: Comparison between mean beta activity concentrations in tomato samples of the study area and WHO bench mark.

Figure 7: shows the bar chart comparison of mean beta activity concentrations in tomato samples of the study area and WHO (2008) guidelines for vegetables bench mark. The result indicates that all the beta activity concentrations in tomato samples across the study area were within the range of $0.17008 \pm 0.00457 \mathrm{~Bq} / \mathrm{L}$ to $0.36133 \pm 0.00655 \mathrm{~Bq} / \mathrm{L}$ which are below the WHO bench mark.

\section{CONCLUSION}

In conclusion, from the above discussion based on the findings of the study, it can be deduced that all the Vegetable samples analyzed have significant radiological health burden on the environment and the populace except in pepper which was at location B (Azbak) where value of $0.09670 \pm 0.00260 \mathrm{~Bq} / \mathrm{L}$ alpha activity was found which is below WHO guideline for vegetable of $0.1 \mathrm{~Bq} / \mathrm{Kg}$. It is therefore recommended that efforts should be intensified to identify further sources of contaminants in the study area with a view to addressing the long standing renal and kidney failure scenario experienced by large group in the study area.

\section{Acknowledgement}

The authors will like to acknowledge Physics Department, Bayero University, Kano. The author also acknowledge the Center for Energy Research A. B. U. Zaria, Center for Renewable Energy Research Bayero University, Kano and all Physics Department of Bayero University Kano staff for their support and using their facilities. 


\section{REFERENCES}

Abba, T. H. (2013). Measurement of Radioactivity in Water and Sediments of River Yobe, North eastern Nigeria. Unpublished M.Sc. Radiation Biophysics Thesis, Faculty of Science, ABU Zaria.

Addis, W. \& Abebaw A. (2017). Determination of heavy metal concentration in soils used for cultivation of Allium sativum L. (garlic) in East Gojjam Zone, Amhara Region, Ethiopia. Cogent Chemistry, 3: 1419422. Retrieved from: https:/ / doi.org/10.1080/23312009.2017.1419422

Adewumi,A.,A,(2016):Evaluation of the gross alpha and beta radioactivity in some agricultural product (Vegetable and fruits) obtained in Niger delta region of, Journal of enronmental pollution and human health, vol 4 :pp 78-82.

Amaral, E.C.S., Rochedo, E.R.R., Paretzke., H.G,(1998). The radiological impacts of agricultural activities in an area of high natural radioactivity .Radiation protection Dosimetry 45: 289-292.

Badran, H.M., Sharshar, T., and Elnimer T. (2003).Levels of 137Cs and 40K in edibles Parts of some vegetables consumed in Egypt. Journal of Environmental Radioactivity 67, 181190.

IAEA, (1989). International Atomic Energy Agency, Measurement of radionuclides in food and the environment. A guidebook, Technical Report Series No. 295, IAEA, Viena

Isa N F, Haladu B,. Ibrahim M U, Tijjani B I, and Umar I D (2021) “Determination of Natural Radionuclide in Sediments of River Jakara Kano, Nigeria Using Gamma Ray Spectrometry and Multivariate Statistical Tool" NIJOSAR Vol 2, Issue 1 page 84-95. www.nijosar.yumsuk.edu.ng

Isa, N. F., Gana, U. M., Ibrahim, U.M., Ahmed, F., Said, M., Salihu, I. M., Haladu, B., Bello, A., Bala, S., and Ibrahim, A. M., (2018) "Comparative Analysis on the Effect of Heavy Metals: A case study of Selected states in Nigeria" Bayero Journal of Pure and Applied Science 11(1):323-329

Isa, F. N., Ibrahim, U. M., Ahmed, F. and Ibrahim, Y. Y. (2017) "Study of Soil-Plant Heavy Metals Relation and Transfer Factor Index of Vegetable Amaranths and Sunflower in some Selected Areas within Kano state , Nigeria" Bayero Journal of Physics and Mathematical Sciences, 8(1): 154-166

Martinsson, J. (2010). Changes in the Course of the River Komadugu Yobe during the

20th Century at the Border between Niger and Nigeria. Unpublished M.scEngineering Geology Thesis, Lund University. P. 1-4

Mustapha (2019).Assessment of Gross Alpha and Beta Radioactivity in Surface and Ground Water of Komadugu -Yobe Riverine,Dutse Journal of Pure and AppliedSciences,5(1):p35-47.

Olomo, J.B., (1990). Natural radionuclide content of some Nigeria foodstuffs.Nuci.Inst. And Methods in Phys. Res. A299:666-669.

Shanthi G., Maniyan C.G, Allan Guana Ray G, Thamp K.J, (2009). Radioactivity in food crops from high background radiation area in South west India. Current Science, Vol.97, No 9 .

Thiry, Y., Goor, F, and Riesen, T, (2002). The true distribution and accumulation Ofradiocaesium in stem of Scots Pine (PinusSylvestris L).Journal of Environmental Radioactivity Vol.60.

WHO, (2008).Guidelines for drinking water quality and other screening levels of various categories of food. $6^{\text {th }}$ ed., World Health Organization, Geneva, Switzerland.

Yobe State Physical Settings, YSPS (2010). Location, Geology, Climate and

Vegetation. Retrieved from: http://www.onlinenigeria.com/yobe-state/?blurb=382 